\title{
土壌伀染性ムギモザイク病ウイルスの 純化ならびに電子顕微鏡観察
}

\author{
斎 藤 康 $*^{*} \cdot$ 高 梨 和 雄* ${ }^{*}$ 岩 田吉 人 $^{*}$
}

Yasuo Saito, Kazuo Takanashi and Yoshito Iwata:

Purification and morphology of Japanese soil-borne wheat mosaic viruses.

\section{I. 緒言}

わが国の土壤伝染性ムギモザイク病の5ち、コムギ 縞萎縮病(コムギイエローモザイク病) とムギ類萎縮病 (ムギ類グリーンモザイク病)とは病徽， X 体の形態 その他に顕著な差が認められることから, 土壤伝染法 などの性質に類似点があるにもかかわらず，一応別種 のウイルスとして取扱われて来た。しかし米国では,

H. H. McKinney $は$ wheat mosaic-rosette virus, wheat yellow mosaic virus をそれぞれ Marmor tritici var. typicum McKinney, Marmor tritici var. fulvum McKinney として分類し柔統として扱つてい る。また平井ら 3 はコムギ縞萎縮病々葉を超溥切片と して電顕によつて観察したが, ウイルス像を認めてい ない。著者らはウイルスの純化を行い, 形態を明らか にすることは, 両者間の類縁関係を明らかにし, また 今後研究をすすめるための基礎となると考えて実験を 行なつた。

実験を行ならに当り病土, 病株を恵与いただいた農 林省関東東山農業試験場病理研究室員各位ならびに茨 城県農業試験場石岡試験地 渡辺文吉郎技師, 電子顕 微鏡撮影に種々御援助を5けた専売公社秦野たばこ 試験場 日高博士および病理研究室員各位, 家畜衛 生試験場 高橋力男技官, ラテックス粒子を御分与下 さつた北大農学部 四方英四郎助教授に深謝の意を表 する。

\section{II. 供試ウイルスと純化法}

1）供試ウイルス コムギ縞萎縮病 (WYMV)，ム ギ類萎縮病 (WGMV) の 2 種類のウイルスを用いた。 WYMV は茨城県農業試験場石岡試験地から採取した 病土を入れた農業技術研究所内ニンクリート枠に発病 した皇田小麦病葉より精製したが，病葉は黄化，かす り状細斑モザイク，えそなど典型的な縞萎縮病の病徴

* 農業技術研究所
を呈していた。WGMV は埼玉県潖巣市関東東山農業 試験場围場で rosette，捲縮，条斑など典型的グリー ンモザイク症状を呈していた早小考病葉より精製し た。

2) 純化法 病葉を承結後, $M / 10$ phosphate buffer (pH 7.0) を加えて homogenize した後ガーゼでろ過 し, クロロホルムを $20 \%$ 容加之強振後 15 分間振燙 した。これを静置後, 低速阌沈 (3,000 rpm 15 分) すると 3 相に分れる。最上層はウイルスを含む液相で あり，中間層は植物体蛋白とクロロホルムとがゲルを 作り固体相となり，最下部の層は過剩のクロロホルム が葉緑素を溶解して緑色の液相となつている。その最 上畨をピペットを用いて採取した。この操作によつて ウイルス蛋白を健全蛋白より汪ぼ分離できたが，な お不純物を含むのでさらに純化するため differential centrifugation を行なつた。高速遠沈は Spinco E型 により行ない, $29,500 \mathrm{rpm}(56,000 \mathrm{~g}) 1$ 時間, 低速 遠沈は $3,000 \mathrm{rpm}(1,000 \mathrm{~g}) 15$ 分でこれを 3 回くり かえした。得られた pellet は無色透明ゼリー状で， これを水に溶解すると蛋白石光を呈する。以上の操作 を図示すると第1図の通りである。

このようにして精製したウイルスは，コムギに病原 性を有し，それぞれコムギ縞萎縮病，么ギ類婪縮病に 特有の病致をあらわした。

\section{III. ウイルスの電子顕微鏡観察}

上記の方法で得られた精製ウイルスを蒸留水で稀釈 し、コロジオン膜をはつたメッシュ上に滴下して乾燥 させ,ク口ム蒸着または白金・パラジウム蒸着による shadowing を行なつた。 sample 中にラテックス粒子 (Dow polysterene latex No. LS-063-A, 粒子直径 $557 \mathrm{~m} \mu$ ) を加光，これを基準として長さの測定を行な つた。

WYMV，WGMV につき各 300 個を測定した。結 果は第 2 図の通りであり, WYMV, WGMV ともに 


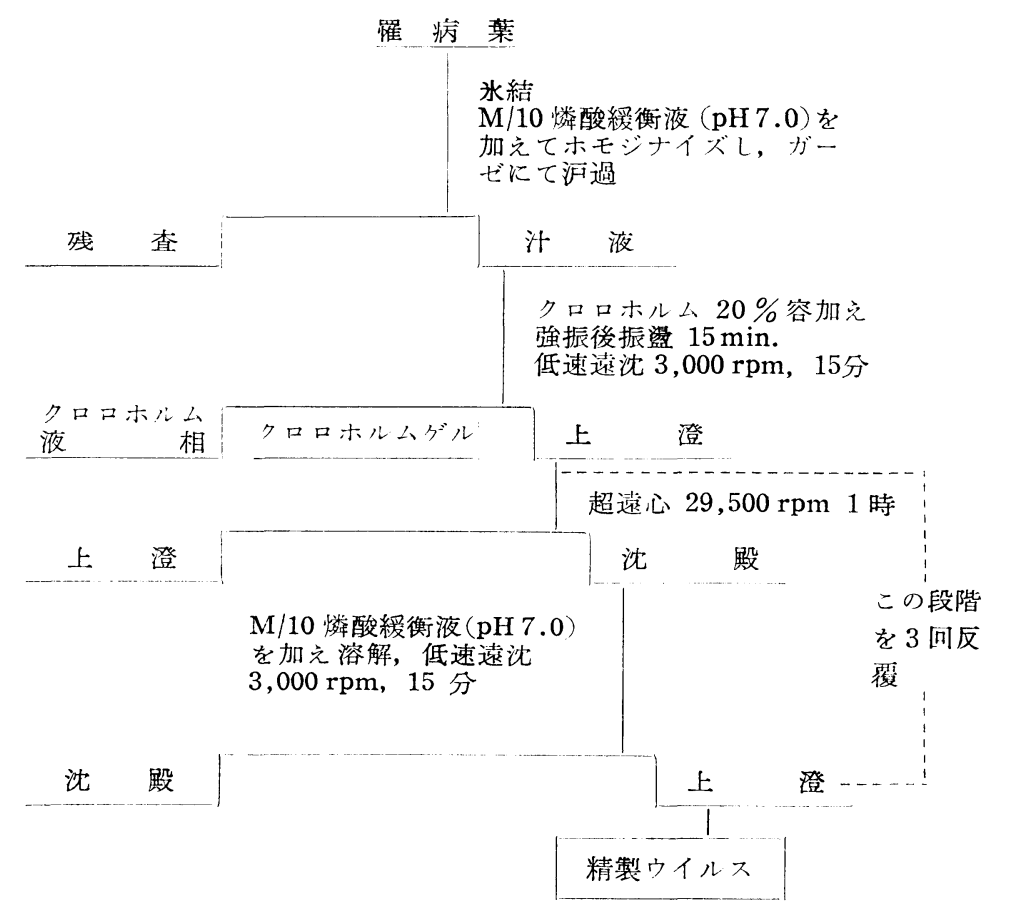

第1目純化操作
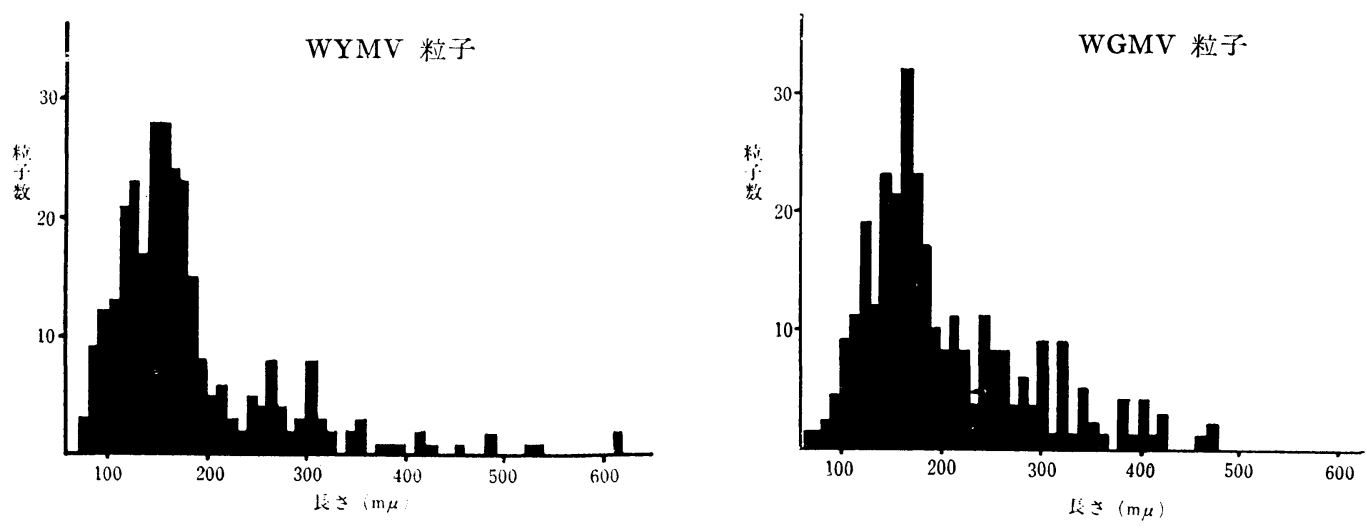

第2図 WYMV,WGMV 粒子の長さの分布

桿状䉼子で, WYMV は長さ $120 \sim 180 \mathrm{~m} \mu$ (mode 150 〜 $160 \mathrm{~m} \mu$ ) が多く，幅は $25 \mathrm{~m} \mu$ であつた。WGMV は $120 \sim 180 \mathrm{~m} \mu$ (mode $170 \mathrm{~m} \mu$ ) が多く, 幅は $25 \mathrm{~m} \mu$ であり, 両者間に明らかな形態的差異は認められな い。な打健全植物にはかかる桿状粒子は認められなか つた。

\section{IV. 考察}

WYMV, WGMV 両者間に形態的な差を認めない
ことは伝染法, その他の諸性質の共通であることと相 まつて，この闭ウイルスの類縁関係が非常に密接であ ることを暗示する。Gold, McKinney ら'は米国で土 壤伝染性コムギウイルス病の病植物汁液を淔接 grid に spray することによつて病原ウイルスの形態を観 察しているが, wheat mosaic-rosette virus, wheat yellow mosaic virus は長さ $128 \mathrm{~m} \mu$ (mode), 幅 24.6

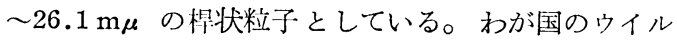
スと比較すると, 幅はほぼ一致し, 長さがやや短い。 
ま异これより先 Hebert ${ }^{2)}$ は，硫安による塩析法を用 いて桿状粒子を電㗼観察している。それによると幅約 $28 \mathrm{~m} \mu$ 長さ $400 \sim 700 \mathrm{~m} \mu$ で, わが国のウイルスと比 較して長さが著しく長いが，これは end-to-end aggregationのためではないかと考えられる。

\section{V. 摘 要}

1）コム科縞娄縮病，ムギ類萎縮病の両ウイルスを クロロホルム処理，分劃遠心法によつて純化した。

2）兩ウイルスの形態を電子顕微鏡観察により比較 した。その結果, 両者とも桿状粒子で WYMV は長 さ $120 \sim 180 \mathrm{~m} \mu$ (mode $150 \sim 160 \mathrm{~m} \mu$ ) が最も多く, WGMV は長さ $120 \sim 180 \mathrm{~m} \mu$ (mode $170 \mathrm{~m} \mu$ ) が最

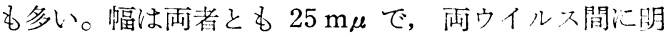
らかな形態的差巽を認めなかつた。

(1960. 9. 28. 受理)

\section{引用交献}

1) Gold, A. H., Scott, H. A. and McKinney, H. H. (1957). Plant Disease Reptr. 41 (4) : 250 $\sim 253$.

2) Hebert, T. T. and Coleman, N. T. (1955). (Abst.) Phytopath. $45: 348$.

3) Hirai, T. and Matsui, C. (1956). Forsch. Gebiet Pflanzenkrankh., Kyoto, 6 (2): 61 72.

\section{Summary}

Purification of two soil-borne viruses, namely wheat yellow mosaic virus and wheat green mosaic virus, was made. The morphology of these viruses was examined by the electron microscope.

Purification procedure was as follows : juice from the diseased leaves was emulsified by adding one-fifth volume of chloroform. The emulsion was then centrifuged to give three layer separation. The top aqueous layer was found to contain the virus, the bottom chloroform layer contained the chlorophyll, and the middle compact plug formed by the chloroform gel contained protein and cellular debris. The virus was further purified by three cycles of differential centrifugation. The final preparation was infectious for wheat plants when rubbed on the leaves with carborundum.

Electron microscopic examination of the purified preparation showed the presence of straight rod-shaped particles in both viruses. These particles were not found in a preparation from healthy plant leaves.

The most frequent length of the virus particles was $120-180 \mathrm{~m} \mu$ (mode $150-160 \mathrm{~m} \mu$ ) in the wheat yellow mosaic, and $120-180 \mathrm{~m} \mu$ (mode $170 \mathrm{~m} \mu$ ) in the wheat green mosaic. The average width of both viruses was $25 \mathrm{~m} \mu$. As shown by these results, the two viruses were indistinguishable in size and shape of particles.

(National Institute of Agricultural Sciences, Tokyo, Japan) 
Plate I.
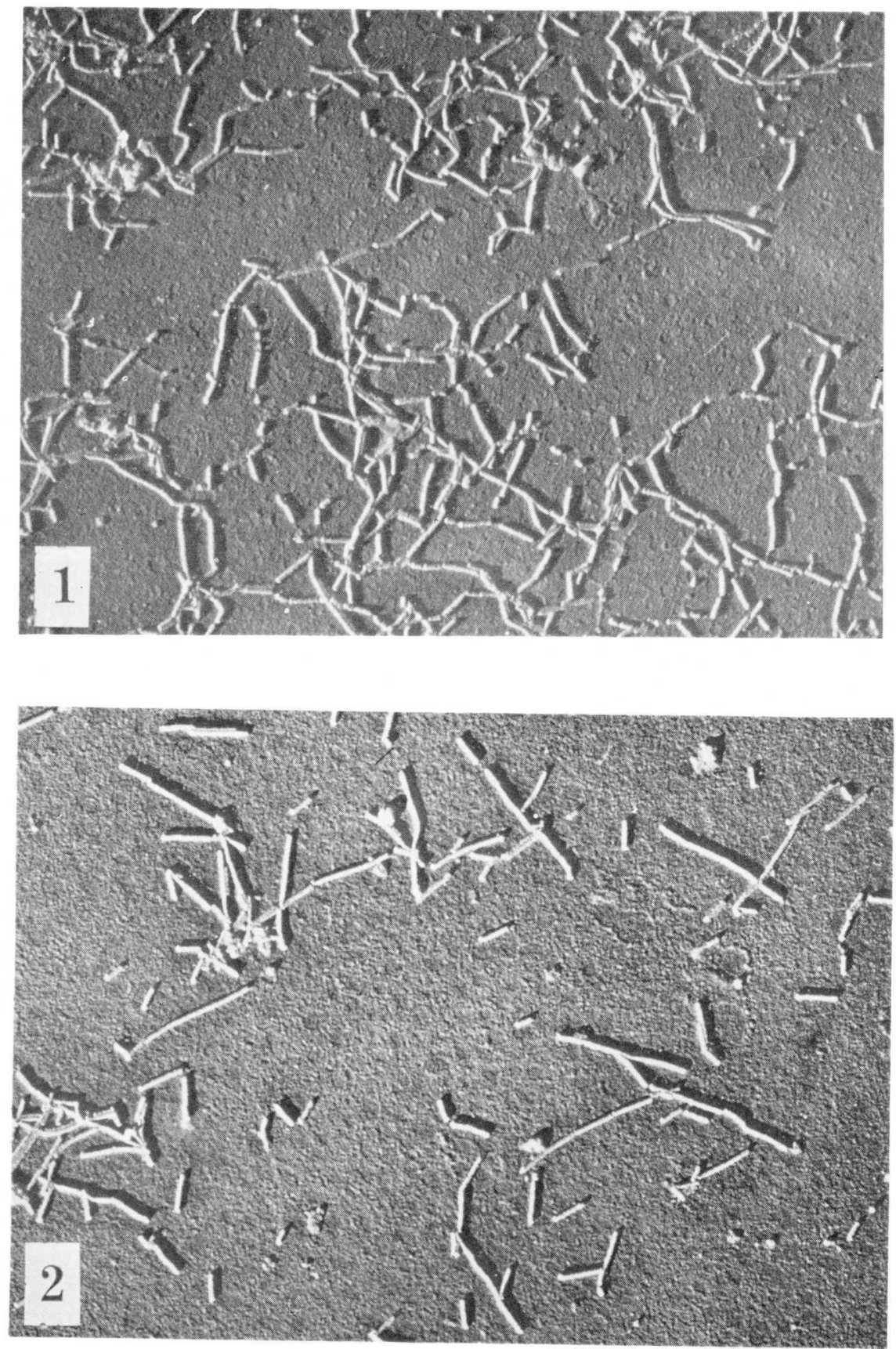

$$
\begin{aligned}
& \text { 1. コム斗縞萎縮病ウイルス }(\mathrm{WYMV}) \times 25,000 \\
& \text { 2.ムギ類萎縮病ウイルス }(\mathrm{WGMV}) \times 25,000
\end{aligned}
$$

